\title{
Foreign Direct Investment in GCC Countries: The Essential Influence of Governance and the Adoption of IFRS
}

\author{
Costas Siriopoulos ${ }^{1}\left(\mathbb{D}\right.$, Athanasios Tsagkanos ${ }^{2, *}$, Argyro Svingou ${ }^{3}$ and Evangelos Daskalopoulos 4 \\ 1 College of Business, Zayed University, Abu Dhabi 144534, United Arab Emirates; \\ Konstantinos.Syriopoulos@zu.ac.ae \\ 2 Department of Business Administration, University of Patras, 26504 Patras, Greece \\ 3 School of Social Sciences, Hellenic Open University, Parodos Aristotelous 18, 26335 Patras, Greece; \\ svingoy.argyro@ac.eap.gr or asviggou@upatras.gr \\ 4 Department of Management Science and Technology, University of Patras, 1 Megalou Alexandrou Str., \\ 26334 Patras, Greece; adaskalop@upatras.gr \\ * Correspondence: atsagkanos@upatras.gr
}

check for updates

Citation: Siriopoulos, Costas, Athanasios Tsagkanos, Argyro Svingou, and Evangelos

Daskalopoulos. 2021. Foreign Direct Investment in GCC Countries: The Essential Influence of Governance and the Adoption of IFRS. Journal of Risk and Financial Management 14: 264 https://doi.org/10.3390/jrfm14060264

Academic Editor: Shigeyuki Hamori

Received: 4 May 2021

Accepted: 7 June 2021

Published: 10 June 2021

Publisher's Note: MDPI stays neutral with regard to jurisdictional claims in published maps and institutional affiliations.

Copyright: (c) 2021 by the authors. Licensee MDPI, Basel, Switzerland. This article is an open access article distributed under the terms and conditions of the Creative Commons Attribution (CC BY) license (https:/ / creativecommons.org/licenses/by/ $4.0 /)$.

\begin{abstract}
This paper presents an analysis of the factors affecting foreign direct investments, focusing on governance quality and adoption of International Financial Reporting Standards on countries of the Gulf Cooperation Council, which are a special case of study due to their idiosyncratic characteristics, rich natural resources and geographical position. Panel data analysis was conducted, implementing three different models (Fixed Effect, Random Effect, and Arellano Bond Dynamic Model). The results show that the adoption of International Financial Reporting Standards is a strong determinant that promotes foreign direct investments. As regards the governance quality, the block of Gulf Cooperation Council countries has fulfilled the minimum level of governance pre-conditions relative to foreign direct investments. In addition, governance indicators associated with law, rules, and corruption are more influential determinants for foreign direct investments.
\end{abstract}

Keywords: FDI; IFRS; GCC countries; governance; panel data analysis; OLI Paradigm

\section{Introduction}

The GCC ${ }^{1}$ is an important union of states that attracts the world's attention because it is one of the main producers of the world's oil. Therefore, these states play a significant role not only in the energy market but also in the global market. These states differ from the developed and emerging countries. They are predominately segmented markets and they are very sensitive to regional political events (Arouri and Rault 2010) while their idiosyncratic characteristics are a special subject under the view of international cooperation and convergence.

The union of GCCs was created in 1981 for political and economic cooperation aiming at the integration and coordination of the member states in all fields. In 2003, GCCs created a Custom Union, where they implement common custom tariff, while a monetary unionis in the process. Moreover, all GCCs are members of the Greater Arab Free Trade Area (GAFTA) and of the World Trade Organization (WTO).

International trade and foreign direct investments (FDI) are two of the main expressions of the globalization of the economy and the internationalization of firms. A great part of the empirical research considers FDI and international trade to be complementary (Büthe and Milner 2008; Marchant et al. 2002; Liu et al. 2001; Gopinath et al. 1999). However, international trade and FDI determinants are different across countries or regions (Tintin 2013; Villaverde and Maza 2015) encouraging the view that the nature of FDI will move more toward being a substitute rather than a complement to trade (Globerman 2017).

The choice of location is a crucial factor for foreign investments (Dunning and Lundan 1998). Although the GCCs are rich in natural resources, open to trade, and possess wealth, 
they attract less FDI, according to the report of IMF (2018). This remark raises concerns on whether this area may be a friendly business environment under the view of the structural components of the quality of governance and the financial environment. The efficient adoption and implementation of a governance and accounting system is strongly associated with the idiosyncratic characteristic of a country or a region (Shleifer and Vishny 1997; Black et al. 2010; Márquez-Ramos 2011). Thus, two key issues are addressed in this study. The first concerns the governance and the second the adoption of International Financial Reporting Standards (IFRS). Governance and accounting systems (such as the IFRS) are supplemented. The governance covers operational management and accounting covers financials. Also, common principles guarantee good cooperation and understandability.

This paper builds on Dunning's Eclectic Paradigm and empirically investigates if there exist location advantages throughout the GCC area. We simultaneously investigate governance and IFRS as potential location advantages in this area. We separate each influence in order to evaluate which of them matters more to international investors and traders. This paper makes essential contributions. First, it is an empirical analysis investigating to what extent the OLI Paradigm can be used as a general model to capture particular characteristics by encompassing institutional indicators. Second, it widens the current knowledge about the GCCs, a region with global geopolitical and economic interests. GCCs' economies have gained little attention in empirical research while possessing accumulative wealth and providing a different economic model compared to other countries rich in natural resources. Last but not least, this region is a case study because it concentrates some characteristics of a common market. Our results clearly demonstrate that the adoption of IFRS has a significant impact on FDI. The governance quality has also a significant role, but empirical findings indicate that the impact of IFRS is more significant, signifying that in the field of governance, the GCCs have fulfilled the pre-conditions.

The rest of the study is organized as follows: In the following section, we present the literature review. Section 3 presents the methodology and data description, Section 4 provides the empirical results, and Sections 5 and 6 consist of discussion and conclusions respectively.

\section{Literature Review}

This paper builds on the theoretical framework of the OLI Paradigm (Dunning and Lundan 1998). The Eclectic Paradigm explains the ownership, location, and internalization advantages that may promote FDI. The ownership and internalization advantages are associated with the micro-environment of a firm and its ability to develop intangible assets such as innovation, technology, efficient management, etc. The location advantages refer to the host country's business environment, from which firms may gain some benefits in their operational and productive activities (e.g., political and legal environment, tax system, property rights, cheap labor, market size, etc.). This paper empirically analyzes to what extent the OLI Paradigm can be served as a general model to capture the location determinants of the FDI, focusing on factors associated with the operational and financial management of firms.

Investors need to have a friendly business environment in order to take risks. Thus the first concern is the quality of governance of the host country. Corporate governance may promote economic relationships in terms of trade and investments as they guarantee familiar and secure market environments (Khanna et al. 2006; Gani 2007; Adeoye 2009; Lederman et al. 2013; Buchanan et al. 2012). Indeed, institutions of host countries influence the choice of entry modes (Meyer 2001) as the multinationals' choice of the entry type depends on the governance quality of host countries (Slangen and Tulder 2009).

Some studies focused on the political regime provide evidence that democracies promote FDI if certain terms are respected (Guerin and Manzocchi 2009; Asiedu and Lien 2011). However, Li (2009) argues that both democracies and autocracies may encourage or discourage FDI, noticing that the frequent leadership turnovers are the deterrent factor for attracting FDI. 
Empirical literature shows that GCCs have improved their governance quality and gradually approach the international standards, even though their idiosyncratic characteristics are obvious. According to Baydoun et al. (2012), culture and religion are the two essential elements that influence corporate governance in the region. He argues that the adoption of international practice could be effective in the direction of a good corporate governance system. In the same spirit, Shehata (2015) points that GCCs compared to the wider region of Middle East North Africa countries (MENA), show greater convergence in the international corporate governance standards.

Although the adoption of common governance principles remains a priority for attracting investments, there is the common belief that an effective system of governance should take into account the specific characteristics of each region (Buck and Shahrim 2005; Black et al. 2010; Al-Malkawi et al. 2014). Under this view, Bhatti and Bhatti (2010) propose an Islamic corporate governance model, which combines both Sharia and OECD principles.

Common governance principles form a familiar environment, which is the necessary precondition for investments. Investors need understandable financial information to make decisions. IFRS provide a common accounting language thus diminishing the information costs among countries, reducing investors' uncertainty, and enhancing the reporting quality and the comparability of financial statements across countries. This is crucial to encouraging international investments as well.

Many studies have recognized the significant positive effect of IFRS on increasing FDI inflows across different economic and geographical peripheries (Márquez-Ramos 2011; Gordon et al. 2012; Chen et al. 2014; Daskalopoulos et al. 2016; Kainth and Wahlstrøm 2021). However, the effect of IFRS adoption is dependent on the economic status of each country. The developing countries gain much more FDI inflows than developed countries by the adoption of IFRS (Gordon et al. 2012). This is because developing countries need more international funds compared to developed countries, thus they should secure their access to international institutions such as the IMF and World Bank. It is also supported by the fact that investors' expected returns are higher in emerging economies.

Although the common belief is that IFRS have a positive effect on international trade and FDI, Nnadi and Soobaroyen (2015) provide contrary evidence for the African countries. They find that institutional structures such as the legal system and the level of corruption are more important factors than IFRS adoption for the FDI increase in these countries, highlighting the primary role of the institutional and legal framework of a country. The findings of (Nnadi and Soobaroyen 2015) reinforce the view that a de jure implementation of IFRS is not sufficient to gain the benefits that the literature indicates.

The issue of compliance is crucial, as it determines the effectiveness of standards, and it is associated with institutions of countries. Only the adoption of IFRS, without the full compliance of the disclosure requirements, reduces their efficacy (Hodgdon et al. 2008). Furthermore, between countries with different legal regimes, the interpretation and implementation of IFRS may be different (Márquez-Ramos 2011). Thus, the decision of IFRS adoption presupposes some institutional arrangements and the isolated changes in accounting and disclosure systems should be accompanied by simultaneous improvements in the country's institutions (Amiraslani et al. 2013).

Although GCC countries have been applying IFRS for decades, there are few studies regarding the benefits of the IFRS adoption. Alsaqqa and Sawan (2013) investigate the impact of IFRS in the UAE stock exchange and their findings reveal that the adoption of IFRS has improved the quality of financial reporting. Apergis (2015) provides similar conclusions for the MENA countries. He points out that the level of financial reporting quality may differ across countries due to the different institutional, economic, and regulatory frameworks.

In terms of integration, empirical research indicates that IFRS adoption promotes integration into capital markets (inter alia Covrig et al. 2007; Cai and Wong 2010). Alnodel (2014) shows that the adoption of IFRS by GCCs stock markets does not affect the 
integration into the capital market, explaining that some other institutional elements may block the role of common accounting standards. Indeed, the lack of qualified accounting professionals, the ineffectiveness of external auditors, the existing accountant and legal framework, the organization of the financial market, and the lack of education on IFRS are documented as factors that justify the noncompliance to IFRS in GCCs (Al-Shammari et al. 2008; Aljifri 2013; Hassan et al. 2014; Al-Mannai and Hindi 2015; Nurunnabi 2018).

All in all, governance, and accounting systems (as the IFRS) are supplementary. Common principles of governance and accountancy guarantee understandability and comparability and thus strengthen good cooperation and common legitimacy. The change in the degree of the positive effect of governance and IFRS on the internationalization perspective of GCCs would be proof if these preconditions are fulfilled. Thus, our hypotheses are formulated as follows:

Hypotheses 1 (H1). Institutional quality (macro corporate governance) does not positively affect (on average) FDI inflows.

Hypotheses 2 (H2). IFRS adoption does not positively affect (on average) FDI inflows.

\section{Methodology and Data Description}

The full dataset contains annual panel data for six GCC countries (Bahrain, Kuwait, Oman, Qatar, Saudi Arabia, and the United Arab Emirates), for the period 1996 to 2017. Our goal is to investigate whether the governance and the adoption of IFRS encourage FDI. Thus, our dependent variable is the natural $\log (\mathrm{Ln})$ of Foreign Direct Investment, net inflows in current USD. We approximate corporate governance at the macro level using the six variables proposed by Kaufmann et al. (2009) which measure the six dimensions of governance. IFRS adoption (adifrs) is a dummy variable which equals 1 if a country has adopted IFRS or 0 otherwise, in our model. Also, we investigate the level of infrastructure development in the host countries through the number of telephones per 100 populations (Asiedu and Lien 2011). Furthermore, we adopt the control variables GDP, GDP Growth, GDP per capita to capture the dynamics of each market. Table A1 in Appendix A, presents the variables considered in the analysis and data sources.

We report the descriptive statistical measures in Table 1. More precisely, Table 1 shows the average, the median, the minimum and maximum values, standard deviation, and the number of observations in the sample ${ }^{2}$. Some interesting points arise from the statistics of governance indicators. According to the description of Kaufmann et al. (2009), the values range from $-2.5=$ weak to $2.5=$ strong. All mean governance indicators are a little more than zero indicating a moderate governance performance. The average value of the voice and accountability indicator is negative, which indicates an austere and restrictive social environment. As for the infrastructure variable, the average value shows good infrastructure development in GCCs.

Table 1. Descriptive Statistics 1996-2017.

\begin{tabular}{ccccccc}
\hline Variables & Mean & Median & Maximum & Minimum & Std. Dev. & Obs \\
\hline LnFDI & $4,060,000,000$ & $1,290,000,000$ & $39,500,000,000$ & $-2,170,000,000$ & $7,100,000,000$ & 105 \\
ADIFRS & 0.714286 & 1 & 1 & 0 & 0.45 & 105 \\
LnGDP & $163,000,000,000$ & $106,000,000,000$ & $756,000,000,000$ & $6,100,000,000$ & $181,000,000,000$ & 105 \\
GROWTH & 5.13088 & 4.410275 & 26.17025 & -7.0761 & 5.014516 & 105 \\
GDPPC & $30,482.05$ & $23,649.37$ & $88,564.82$ & 6254.953 & $19,839.45$ & 105 \\
GE & 0.38779 & 0.391808 & 1.509872 & -0.37478 & 0.415555 & 105 \\
COR & 0.45304 & 0.390058 & 1.567186 & -0.33115 & 0.455451 & 105 \\
PV & 0.338202 & 0.455153 & 1.223623 & -1.33542 & 0.64316 & 105 \\
RQ & 0.418925 & 0.473385 & 1.120548 & -0.30826 & 0.329536 & 105 \\
RL & 0.435359 & 0.471937 & 0.958523 & -0.15068 & 0.242224 & 105 \\
VA & -1.00049 & -0.99983 & -0.24381 & -1.9072 & 0.415364 & 105 \\
PHONE & 106.74 & 118.3071 & 214.7349 & 0.670641 & 57.68636 & 105 \\
\hline
\end{tabular}


We investigated the possible effects of independent variables on FDI, implementing three different panel models, fixed effect, random effect, and Arellano-Bond Estimator. Each model reports results based on different assumptions thus results for these three different models allowed us to compare them for robustness.

The fixed effect model investigates group differences in intercepts, assuming the same slopes and constant variance across the cross-sections (countries). We considered this effect, as it allowed us to capture unobserved heterogeneity across countries where it is fixed over time. Equation (1) below presents our fixed effect model:

$$
\begin{gathered}
\operatorname{LnFDI}_{i t}=\left(a+u_{i}\right)+\beta_{1} \text { ADIFRS }_{i t}+\beta_{2} G O R_{i t}+\beta_{3} L n G D P_{i t}+\beta_{4} G R O W T H_{i t}+\beta_{5} G D P P C_{i t} \\
+\beta_{6} G E_{i t}+\beta_{7} P_{H O N E_{i t}}+\beta_{8} P V_{i t}+\beta_{9} R Q_{i t}+\beta_{10} R L_{i t}+\beta_{11} V A_{i t}+\varepsilon_{i t}
\end{gathered}
$$

where, cross-sections (countries) are expressed by $i=1,2,3,4,5,6$ and $t$ is the time period, that is, $t=1,2,3 \ldots 22$. Also, $\varepsilon_{i}$ is the error term $\varepsilon \sim \operatorname{IID}\left(O, \sigma_{\varepsilon}^{2}\right), u_{i}$ is a random variable that is part of the intercept $\alpha$ under the fixed effects model and it is assumed that it is uncorrelated with explanatory variables. Equation (1) is estimated by using a least squares dummy variable (LSDV) estimator.

However, the fixed effect model does not allow for the variation across countries to be random and uncorrelated with the dependent and independent variables included in Equation (1). Thus, we estimate the random effects model, as well:

$$
\begin{gathered}
\operatorname{LnFDI}_{i t}=a+\beta_{1} \text { ADIFRS }_{i t}+\beta_{2} G_{O P R_{i t}}+\beta_{3} L n G D P_{i t}+\beta_{4} G R O W T H_{i t}+\beta_{5} G D P P C_{i t}+\beta_{6} G E_{i t} \\
+\beta_{7} P H O N E_{i t}+\beta_{8} P V_{i t}+\beta_{9} R Q_{i t}+\beta_{10} R L_{i t}+\beta_{11} V A_{i t}+\left(\varepsilon_{i t}+u_{i t}\right)
\end{gathered}
$$

In contrast with the fixed effect model, the random effect model gives estimates variance components for countries and error, assuming the same intercepts and slopes. In Equation (2), the random component $u_{i}$ is a part of the errors means that the difference among the countries lies in their variance of the error term and not in their intercepts. The random effects model is estimated by the GLS estimator.

A frequent phenomenon in economics is the dependence of a variable on its own previous value. For such cases, autoregressive (AR) models are useful because they specify that the dependent variable may be linearly determined on its own previous values and describes certain time-varying processes. The following model expresses an autoregressive process:

$$
Y_{i t}=\beta_{1} Y_{i, t-1}+\beta_{2} X_{i t}+u_{i t}
$$

Some problems may arise from Equation (3) related to the endogeneity of variables and to the error terms, as the fixed effects, which are contained in the error term, consist of the unobserved country-specific effects and the observed specific errors, that is:

$$
u_{i t}=u c_{i}+e_{i t}
$$

The solution to such a problem is using the two-stage least squares (2SLS) regressions.

However, the existence of lagged dependent variable increases autocorrelation in the model. The Arellano-Bond estimator solves these problems as transforms Equation (3) in first differences:

$$
\Delta Y_{i t}=\beta_{1} \Delta Y_{i, t-1}+\beta_{2} \Delta X_{i t}+\Delta u_{i t}
$$

Because of Equation (4), the first differenced error term equals to $\Delta u_{i t}=e_{i t}-e_{i t-1}$, thus the fixed effects in the error terms are not time-varying.

Therefore, we estimate the following model in our case as below:

$$
\begin{aligned}
& \Delta L n F D I_{i t}=a_{i}+\beta_{1} \Delta L n F D I_{i t-1}+\beta_{2} A D I F R S_{i t}+\beta_{3} \Delta G O R_{i t}+\beta_{4} \Delta L n G D P_{i t}+\beta_{5} \Delta G R O W T H_{i t} \\
& +\beta_{6} \Delta G D P P C_{i t}+\beta_{7} \Delta G E_{i t}+\beta_{8} \Delta P H O N E_{i t}+\beta_{9} \Delta P V_{i t}+\beta_{10} \Delta R Q_{i t}+\beta_{11} \Delta R L_{i t} \\
& +\beta_{12} \Delta V A_{i t}+\Delta u_{i t}
\end{aligned}
$$




\section{Empirical Findings}

In this section, we present the results of our model. At each stage of analysis, FDI inflows represent the dependent variable, while the other variables are used as independent regression variables.

The question that arises from a panel analysis is the choice of the most appropriate model between fixed effect and random effect. This was answered using the Hausman test (Hausman 1978), which reports the appropriate model for each case. The null hypothesis of the test (H1) considers that the preferable model is that of random effect, while the alternative hypothesis (H2) supports the fixed effect model. According to Table 2, the Chi-Sq statistic value is 29.51 and the respective $p$-value is equal to 0.0010 . Therefore, we easily concluded that the fixed effect model is better for the current analysis, compared to the random effect model. However, we still reported the random effect results as they are not significantly different than those of fixed effect.

Table 2. Correlated Random Effects-Hausman Test.

\begin{tabular}{ccc}
\hline Test Summary & Chi-Sq. Statistic & Prob. \\
\hline Cross-section random & 29.51 & 0.0010 \\
\hline
\end{tabular}

Our results are presented in Table 3 The coefficient of determination R-squared $(=0.52)$ shows the variability rate of the dependent variable explained by the independent variables. In this case, Foreign Direct Investment inflows are explained as $52 \%$ by the independent variables (IFRS adoption, governance quality, GDP, GDP Growth, GDP per capita, and infrastructures). The adjusted determinant, Adj R-squared $(=0.46)$, is the same as the $\mathrm{R}$-squared, but it is adjusted by the number of cases and variables.

Table 3. Results of Fixed Effect, Random Effect, and Arellano-Bond Estimator.

\begin{tabular}{|c|c|c|c|c|c|c|c|c|c|c|c|c|}
\hline \multirow[b]{2}{*}{ Variables } & \multicolumn{4}{|c|}{ Fixed Effects } & \multicolumn{4}{|c|}{ Random Effect } & \multicolumn{4}{|c|}{ Arellano-Bond Estimator } \\
\hline & Coef. & $\begin{array}{l}\text { Std. } \\
\text { Err. }\end{array}$ & $t$-Stat & $p>t$ & Coef. & $\begin{array}{l}\text { Std. } \\
\text { Err. }\end{array}$ & $t$-Stat & $p>t$ & Coef. & $\begin{array}{l}\text { Std. } \\
\text { Err. }\end{array}$ & $t$-Stat & $p>t$ \\
\hline LnFDI L1 & & & & & & & & & 0.31 & 0.1 & 3.06 & 0.00 \\
\hline ADIFRS & 2.15 & 0.51 & 4.23 & 0 & 1.06 & 0.44 & 2.39 & 0.017 & 1.42 & 0.50 & 2.86 & 0.00 \\
\hline COR & 0.01 & 0.49 & 0.03 & 0.976 & -0.46 & 0.52 & -0.89 & 0.374 & 1.63 & 0.72 & 2.26 & 0.02 \\
\hline LnGDP & -1.51 & 0.83 & -1.82 & 0.072 & 0.59 & 0.17 & 3.47 & 0.001 & -1.49 & 0.88 & -1.69 & 0.09 \\
\hline GROWTH & 0.06 & 0.03 & 2.21 & 0.03 & 0.11 & 0.03 & 3.81 & 0.00 & 0.10 & 0.02 & 3.87 & 0.00 \\
\hline GDPPC & 0.00 & 0.00 & 1.34 & 0.183 & 0.00 & 0.00 & -1.25 & 0.211 & 0.00 & 0.00 & 0.51 & 0.61 \\
\hline GE & 0.49 & 0.83 & 0.6 & 0.553 & 1.67 & 0.64 & 2.6 & 0.009 & -0.61 & 0.90 & -0.67 & 0.50 \\
\hline PHONE & 0.01 & 0.01 & 2.54 & 0.013 & 0.00 & 0.00 & -0.18 & 0.853 & 0.01 & 0.01 & 1.30 & 0.19 \\
\hline PV & 1.08 & 0.53 & 2.07 & 0.042 & 0.51 & 0.29 & 1.72 & 0.085 & 0.25 & 0.52 & 0.48 & 0.63 \\
\hline $\mathrm{RQ}$ & -0.22 & 0.67 & -0.33 & 0.743 & 0.22 & 0.67 & 0.330 & 0.741 & -1.85 & 0.86 & -2.15 & 0.03 \\
\hline RL & -1.99 & 0.83 & -2.39 & 0.019 & -2.60 & 0.87 & -2.99 & 0.003 & 0.36 & 0.98 & 0.36 & 0.72 \\
\hline VA & 0.18 & 0.98 & 0.19 & 0.853 & -1.28 & 0.43 & -2.99 & 0.003 & -0.79 & 0.99 & -0.80 & 0.42 \\
\hline constant & 55.11 & 19.49 & 2.83 & 0.006 & 4.49 & 3.99 & 1.12 & 0.261 & 48.52 & 21.22 & 2.29 & 0.02 \\
\hline Obs & \multicolumn{4}{|c|}{98} & \multicolumn{4}{|c|}{98} & \multicolumn{3}{|c|}{$\begin{array}{l}\text { Arellano-Bond dynpandata } \\
\text { Number of obs }\end{array}$} & 72 \\
\hline R-squared & \multicolumn{4}{|c|}{0.52} & \multicolumn{4}{|c|}{0.43} & \multicolumn{3}{|c|}{ Number of groups } & $\begin{array}{c}6 \\
\operatorname{Min}=9\end{array}$ \\
\hline Adjusted R & \multicolumn{4}{|c|}{0.46} & \multicolumn{4}{|c|}{0.64} & \multicolumn{3}{|c|}{ Obs per group: } & $\begin{array}{l}\operatorname{Avg}=12 \\
\operatorname{Max}=15\end{array}$ \\
\hline Log likelihood & \multicolumn{4}{|c|}{2491.94} & \multirow{3}{*}{\multicolumn{4}{|c|}{0}} & \multicolumn{3}{|c|}{ Number of instruments } & 73 \\
\hline F-statistic & \multicolumn{4}{|c|}{8.24} & & & & & \multicolumn{3}{|c|}{ Wald chi2(12) } & 95.82 \\
\hline Prob. (F-statistic) & \multicolumn{4}{|c|}{0} & & & & & \multicolumn{3}{|c|}{ Prob $>$ chi 2} & 0 \\
\hline
\end{tabular}


The H1 hypothesis is rejected both when the $t$-stat is larger than 1.96 (in absolute values) and the $p$-value is larger than 0.05 , in a $5 \%$ significance level. The $t$-stats are the coefficients of regressions divided by their respective standard errors. We observe that $t$-statistic for the adoption of IFRS (ADIFRS) is 4.23, indicating a strong positive and significant impact on FDI. Therefore, we can reject the null hypothesis H1, meaning that the adoption of IFRS positively affects foreign direct investments.

In addition, Growth is a statistically significant variable and has a positive effect on FDI inflows $(t$-stat $=2.21$ and $p$-value $=0.03)$. As for governance indicators, the fixed effect model showed two indicators to be significant: the political stability and absence of violence index (PV) and the rule of law index (RL). The impact of the former is positive $(t$-stat $=2.07$ and $p$-value $=0.042)$ and the impact of the latter is negative $(t$-stat $=-2.39$ and $p$-value $=0.019)$ on FDI. Also, Infrastructure index positively and significantly affects FDI $(t$-stat $=2.54$ and $p$-value $=0.013)$.

The use of the random effect model has almost the same results as those of the fixed effect method. Table 3 reports the relative results. We observed that $t$-statistic for the adoption of IFRS (ADIFRS) is 2.39 , indicating a strong positive and significant impact on FDI. Therefore, we reject the null hypothesis H1, meaning that the adoption of IFRS positively affects foreign direct investment in the case of random effect also.

GDP and Growth are statistically significant variables and have a positive effect on FDI inflows $(t$-stat $=3.47, p$-value $=0.001$ and $t$-stat $=3.81, p$-value $=0.00$, respectively) . Also, the governance indicators rule of law (RL) and voice and accountability (VA) have a negative and significant effect on FDI, while the statistical power of these two indicators is the same ( $t$-stat equals -2.99 and $p$-value equals 0.003$)$. However, the magnitude of the effects differs (coefficient of RL equals -2.60 and of VA $=-1.28$ ), indicating that the confidence in the rules of society has a greater effect than that of the freedoms.

The use of the Arellano-Bold estimator has almost the same results as those of the fixed effect method. More precisely, the adoption of IFRS positively and significantly affects FDI ( $t$-stat equals 2.86 and $p$-value equals 0.10$)$. Growth is the most important factor among the other factors, while its impact is positive on FDI. Moreover, results show that both the control of corruption (COR) and regulatory quality (RQ) are significant. The control of corruption (COR) positively affects FDI while the influence of regulatory quality (RQ) is significantly negative. Furthermore, the lagged FDI inflows (L1) are a strong determinant of current FDI, meaning that a good performance in the previous FDI promotes current FDI.

\section{Discussion}

We employ three different panel models to specify the impact of the selected variables on FDI. Our results show interesting insights on the adoption of IFRS and the governance quality on FDI.IFRS are well established in the literature in terms of their effects both on the micro and macro levels. We confirm a strong significant and positive effect between IFRS and FDI, obtained by the three models that we have employed. This result is consistent with the previous research (Márquez-Ramos 2011; Gordon et al. 2012; Chen et al. 2014; Daskalopoulos et al. 2016).

Furthermore, the IFRS result highlights the trade interdependences across countries asthe accounting convergence may be a precondition of economic relations (inter alia Irvine 2008; Ramanna and Sletten 2009). GCC countries have developed extensive cooperation with the Western world, while the European Union is the greatest trade partner to them.

Regarding governance, our results indicate that governance is an influential factor for promoting FDI inflows, a result consistent with Gani (2007) and Buchanan et al. (2012). Some other points are interesting as well. The fixed effect results show a positive relationship between political stability and FDI. The detected effect confirms the general view that political uncertainty negatively affects economic growth (Aisen and Veiga 2013).

Furthermore, the Arellano model shows that the control of corruption is positive and statistically significant, indicating that transparency enhances foreign investments. According to the World Bank ${ }^{3}$, the annual worldwide bribery is about USD 1 trillion, noting 
the extension of corruption internationally. Corruption costs not only money but also the efficacy of an investment and more general in the overall economy. Investors do not care so much about the level of corruption, but they avoid the uncertainty which a corrupt deal encompasses, thus corruption may have an adverse impact on foreign direct investment and net capital inflows (Lambsdorff 2003). Also, corruption should be considered because it is associated with economic growth and its influence is much more than other public administrative distortions such as bureaucracy (Papaconstantinou et al. 2013).

The coefficients of voice and accountability, regulatory quality, and rules of law are negative and significant, indicating that restrictions on personal liberty, weak formulation, and implementation of rules and policies are factors that prevent FDI. Kayalvizhi and Thenmozhi (2018) find similar results for a set of emerging countries. These specific variables are the basic infrastructure of a state, as they relate to fundamental principles, such as equality and justice, which contribute to a sense of social and economic trust and security.

On the other hand, we observe that the indicators relative to the confidence of implementation of the law and the rules and the control of the corruption seem to be more important determinants than the others relative to political stability and social liberties. More specifically, political stability has less impact than the other variables of governance in terms of statistical significance and magnitude. We believe this result has the same explanation as Slangen and Tulder (2009), who state that Kaufmann's political stability index measures the likelihood of a sudden regime change due to a terrorism or political violence event. MNEs may pay little attention to this possibility in contrast with the other five dimensions of governance that measure the current governance policies and actions that directly influence investments.

Furthermore, results from fixed effect and Arellano models do not report some influence of voice and accountability index on FDI. We explain this result as evidence that the social or political regimes neither attract nor extract FDI. Therefore, we consider this result consistent with Li (2009) and Asiedu and Lien (2011).

What is more, our results indicate that GDP growth positively and significantly affects FDI, indicating that international investors and MNEs prefer countries with economic growth. Economic growth shows not only the dynamics of production but also a wellorganized product and money market. FDI promotes stock market development and thus economic growth (Tsagkanos et al. 2019).

All in all, GCCs are a block of states that concentrates some special characteristics that have an impact on their social and economic development as well. Notwithstanding their idiosyncrasies, they are very open economies due to their oil exports. Their strategic plan for economic diversification, which is needed, passes through FDI, both for funding such investments and more importantly for gaining new knowledge and innovations. Under this perspective, IFRS and governance quality may help attract investors.

\section{Conclusions}

This paper presents an empirical analysis of the location advantages for the GCC countries, investigating the extent to which institutional factors may promote FDI. We conduct a panel analysis, implementing three different models: (a) the Fixed Effect, (b) the Random Effect, and (c) the Arellano-Bond Dynamic Model. The results clearly indicate that the accounting system is a strong determinant that promotes FDI. More specifically, all three models indicate that IFRS are the most essential factor that encourages FDI.

In relation to the governance quality, the results show that the specific topic of governance is associated with FDI. The confidence in the law and the control of corruption negatively affects the FDI, the other governance indicators do not seem to have statistical significance. All in all, we believe that our results on governance quality indicate that GCCs have fulfilled a minimum level of governance pre-conditions relative to FDI. 
Moreover, we find that GDP growth positively and significantly affects FDI. This result means that international investors and MNEs prefer countries with economic growth because growth implies a well-organized market (Tsagkanos et al. 2019).

The results of this study have important economic implications. First, a better understanding of environments, such as the Gulf countries, is vital for international institutions, investors, and policymakers. International institutions may help GCCs in the field of the educational system to not only adopt IFRS but also implement them in a correct way. Also, they may provide support to GCCs relative to the operation of public administration to isolate distortions in the implementation of the rules. Furthermore, this paper may play an informative role for investors as it provides evidence on FDI in GCCs. Policymakers of GCCs may enhance their efforts into financial reforms, institutional quality, improvement of the business environment to attract FDI and encourage international entrepreneurs (Dkhili and Dhiab 2018; Hussain et al. 2021). Our study also provides some theoretical insights to academic scholars interested in the determinants of FDI.

Finally, as regards the limitations, assessing the gradual impact of the adoption of IFRS on the FDI inflows of countries is limited by the absence of a comprehensive theoretical model for predicting the FDI inflows of countries. However, extensive empirical literature examines the determinants of FDI inflows, and our study was based on this literature as regards the gradual impact of IFRS on FDI inflows. Furthermore, the second limitation of this study was that the available data on a country's decision to adopt IFRS are incomplete. Specifically, we do not know to what extent the firms within a country concede to all of the principles of IFRS. Once the data become available, another interesting extension of this study would be to examine the impact of IFRS adoption by a country not only considering the overall FDI but by separately estimating the inflows of each FDI pattern.

Finally, how firms decide to invest in a country is certainly a complex issue that is not limited to the infrastructures of a host country. Thus, one extension for future research associated with the location advantages except the infrastructures may be the ability of transnational relations to promote FDI. Also, the cultural differences between states could be an interesting task for the research.

Author Contributions: Conceptualization, C.S., A.T. and A.S.; methodology, E.D.; software, E.D.; validation, C.S. and A.T.; formal analysis, C.S.; investigation, A.T.; resources, E.D.; data curation E.D.; writing—original draft preparation, A.S.; writing—review and editing, C.S., A.T. and A.S.; visualization, C.S. and A.S.; Supervision, C.S.; project administration, C.S. All authors have read and agreed to the published version of the manuscript.

Funding: This research received no external funding.

Institutional Review Board Statement: Not applicable.

Informed Consent Statement: Not applicable.

Data Availability Statement: Not applicable.

Conflicts of Interest: The authors declare no conflict of interests. 


\section{Appendix A}

Table A1. Variable description and data sources.

\begin{tabular}{|c|c|c|c|}
\hline Variables Name & ID & Definition & Source \\
\hline $\begin{array}{l}\text { Foreign Direct Investment, } \\
\text { net inflows }\end{array}$ & LnFDI & $\begin{array}{c}\text { Natural logarithm of foreign direct investment inflow data in } \\
\text { current US dollars. }\end{array}$ & World Bank \\
\hline $\begin{array}{l}\text { Adoption of International } \\
\text { Financial Reporting } \\
\text { Standards }\end{array}$ & ADIFRS & $\begin{array}{c}\text { A dummy variable equal to } 1 \text { if a country has adopted IFRS or } 0 \\
\text { otherwise }\end{array}$ & $\begin{array}{l}\text { https://www.iasplus.com/ } \\
\text { en/resources/ifrs-topics/ } \\
\text { use-of-ifrs (accessed on } 20 \\
\text { October 2018) }\end{array}$ \\
\hline Voice and Accountability & VA & $\begin{array}{l}\text { It shows perceptions of which extent a country's citizens are able } \\
\text { to participate in selecting their government, freedom of } \\
\text { expression, freedom of association, and free media. Range: } \\
\text { [-2.5(=weak), } 2.5 \text { (=strong)] }\end{array}$ & \multirow{6}{*}{$\begin{array}{l}\text { The Worldwide Governance } \\
\text { Indicator database } 2009 \\
\text { prepared by Daniel } \\
\text { Kaufmann, World Bank }\end{array}$} \\
\hline $\begin{array}{l}\text { Political Stability and } \\
\text { Absence of } \\
\text { Violence/Terrorism }\end{array}$ & PV & $\begin{array}{l}\text { It captures insights into the likelihood that a government will be } \\
\text { destabilized or overturned by unconstitutional or violent means. } \\
\text { Range: }[-2.5 \text { (=weak), } 2.5 \text { (=strong)] }\end{array}$ & \\
\hline Government Effectiveness & GE & $\begin{array}{l}\text { It captures perceptions of the quality of public services, the } \\
\text { quality of the civil service, and the degree of its independence } \\
\text { from political pressures. Range: [-2.5(=weak), } 2.5 \text { (=strong)] }\end{array}$ & \\
\hline Regulatory Quality & RQ & $\begin{array}{l}\text { It shows insights on the government ability to formulate and } \\
\text { implement strong policies and regulations that promote private } \\
\text { sector development. Range: [-2.5(=weak), 2.5(=strong)] }\end{array}$ & \\
\hline Rule of Law & RL & $\begin{array}{l}\text { It indicates perceptions of which extent agents have confidence in } \\
\text { the rules of society Range: }[-2.5 \text { (=weak), } 2.5 \text { (=strong)] }\end{array}$ & \\
\hline Control of Corruption & COR & $\begin{array}{l}\text { It captures perceptions of the extent to which public power is } \\
\text { exercised for private gain and the dependence of the state on } \\
\text { elites and private interests. Range: }[-2.5 \text { (=weak), } 2.5 \text { (=strong)] }\end{array}$ & \\
\hline GDP & LnGDP & $\begin{array}{l}\text { Ln of GDP in current US dollars, capturing a market factor that } \\
\text { attracts FDI. }\end{array}$ & World Bank \\
\hline GDP Growth & GROWTH & $\begin{array}{l}\text { GDP growth measured by dividing normal GDP with current } \\
\text { year population, capturing a market factor that attracts FDI }\end{array}$ & World Bank \\
\hline GDP per Capita & GDPPC & $\begin{array}{l}\text { GDP per capita in current US dollars scaled by 1000, capturing a } \\
\text { labor cost factor that attracts FDI. }\end{array}$ & World Bank \\
\hline Infrastructure Index & PHONE & The number of telephones per 100 population & World Bank \\
\hline
\end{tabular}

Table A2. Results of Variance Inflation Factor (VIF).

\begin{tabular}{ccc}
\hline Variable & VIF & 1/VIF \\
\hline GE & 4.96 & 0.201675 \\
\hline COR & 4.25 & 0.23522 \\
\hline PHONE & 3.7 & 0.270074 \\
\hline RQ & 3.58 & 0.279273 \\
\hline LnGP & 3.31 & 0.302512 \\
\hline GDPC & 3.27 & 0.305384 \\
\hline RL & 3.02 & 0.330785 \\
\hline ADIFRS & 2.97 & 0.336163 \\
\hline PV & 2.84 & 0.35175 \\
\hline VA & 2.37 & 0.421355 \\
\hline GDPG & 1.48 & 0.676979
\end{tabular}

For identifying the degree of multicollinearity, in our model, we use Variance Inflation Factor (VIF). According to Sheather (2009), a cutoff of 5 is mostly used, while, considering the rule of thumb that if VIF > 10, the multicollinearity is high (Neter et al. 1996), no correlation between two explanatory variables is indicated by the value of 1 and moderate correlation is indicated by a value between 1 and 5 . In our model, no VIF values not exceed the value of 5 , indicating that there is no severe correlation. 
Table A3. Correlation Matrix.

\begin{tabular}{|c|c|c|c|c|c|c|c|c|c|c|c|c|}
\hline & LnFDI & ADIFRS & LnGDP & GDPC & GDPG & GE & PHONE & PV & RL & RQ & VA & COR \\
\hline LnFDI & 1 & & & & & & & & & & & \\
\hline ADIFRS & 0.5358 & 1 & & & & & & & & & & \\
\hline LnGDP & 0.6363 & 0.5403 & 1 & & & & & & & & & \\
\hline GDPC & 0.2043 & 0.3823 & 0.3895 & 1 & & & & & & & & \\
\hline GDPG & 0.1963 & 0.0389 & -0.0364 & 0.4117 & 1 & & & & & & & \\
\hline GE & 0.1239 & -0.0045 & -0.0014 & 0.4138 & 0.1315 & 1 & & & & & & \\
\hline PHONE & 0.5099 & 0.7718 & 0.5875 & 0.3102 & -0.0398 & 0.0945 & 1 & & & & & \\
\hline PV & -0.0865 & -0.2381 & -0.0003 & 0.4138 & 0.2368 & 0.4516 & -0.3368 & 1 & & & & \\
\hline RL & -0.3038 & -0.1351 & -0.214 & 0.487 & 0.2362 & 0.586 & -0.1257 & 0.5755 & 1 & & & \\
\hline $\mathrm{RQ}$ & -0.0442 & -0.0588 & -0.2971 & 0.1137 & 0.1138 & 0.7468 & 0.0285 & 0.1994 & 0.5295 & 1 & & \\
\hline VA & -0.6181 & -0.4532 & -0.5104 & 0.0984 & 0.0356 & 0.1399 & -0.5112 & 0.4734 & 0.4604 & 0.1364 & 1 & \\
\hline COR & -0.0149 & -0.1438 & 0.0039 & 0.4714 & 0.2838 & 0.7782 & -0.1116 & 0.6529 & 0.6728 & 0.5527 & 0.2985 & 1 \\
\hline
\end{tabular}

\section{Notes}

1 The Gulf Cooperation Council (GCC) is a block of countries that includes Bahrain, Kuwait, Oman, Qatar, Saudi Arabia, and the United Arab Emirates.

2 In addition, all the variables included in the panel models are tested for correlation. In Appendix A, Tables A2 and A3 present the results of the Variance Inflation Factor (VIF) and the correlation matrix, respectively.In our model, no VIF values exceed the value of 5 , indicating that there is no severe correlation.

3 http://web.worldbank.org/WBSITE/EXTERNAL/NEWS/0,,contentMDK:20190295 menuPK:34457 pagePK:34370 piPK:3442 4 theSitePK:4607,00.html (accessed on 20 October 2018).

\section{References}

Adeoye, Adewale. 2009. Macro-economic level corporate governance and FDI in emerging markets: Is there a close relationship? Journal of Economics and International Finance 1: 030-043. [CrossRef]

Aisen, Ari, and Francisco Jose Veiga. 2013. How does political instability affect economic growth? European Journal of Political Economy 29: 151-67. [CrossRef]

Aljifri, Khaled. 2013. Challenges of IFRS in GCC countries: Issues of adoption and compliance. Journal of Accounting $\mathcal{E}$ Marketing 2: 405-554.

Al-Malkawi, Husam-Aldin N., Rekha Pillai, and M. I. Bhatti. 2014. Corporate governance practices in emerging markets: The case of GCC countries. Economic Modelling 38: 133-41. [CrossRef]

Al-Mannai, S. Ebtesam, and Nitham M. Hindi. 2015. Adoption of IFRS by listed companies in Qatar: Challenges and solutions. International Journal of Accounting and Finance 5: 1-26. [CrossRef]

Alnodel, Ali. 2014. The Effect of the Adoption of International Financial Reporting Standards on Capital Market Integration in the Gulf Cooperation Council Countries. Paper presented at the First Journal of International Accounting Research Conference, June 5-7; p. 464. Available online: https:/ / af.polyu.edu.hk/media/7235/cc060-the-effect-of-the-adoption-of-ifrs-on-capital-marketintegration-full-paper-words-file-_final.pdf (accessed on 8 June 2021). [CrossRef]

Alsaqqa, Ihab, and Nedal Sawan. 2013. The advantages and the challenges of adopting IFRS into UAE stock market. International Journal of Business and Management 8: 1. [CrossRef]

Al-Shammari, Bader, Philip Brown, and Ann Tarca. 2008. An investigation of compliance with international accounting standards by listed companies in the Gulf Co-Operation Council member states. The International Journal of Accounting 43: 425-47. [CrossRef]

Amiraslani, Hami, George E. Iatridis, and Peter F. Pope. 2013. Accounting for Asset Impairment: A Test for IFRS Compliance across Europe. London: Centre for Financial Analysis and Reporting Research (CeFARR).

Apergis, Nicolas. 2015. The role of IFRS in financial reporting quality: Evidence from a panel of MENA countries. International Journal of Economics and Finance 7: 182. [CrossRef]

Arouri, Mohamed El Hedi, and Christophe Rault. 2010. Oil Prices and Stock Markets: What Drives What in the Gulf Corporation Council Countries? Available online: https:/ / papers.ssrn.com/sol3/papers.cfm?abstract_id=1549536 (accessed on 20 June 2019).

Asiedu, Elizabeth, and Donald Lien. 2011. Democracy, foreign direct investment and natural resources. Journal of International Economics 84: 99-111. [CrossRef]

Baydoun, Nabil, William Maguire, Neal Ryan, and Roger Willett. 2012. Corporate governance in five Arabian Gulf countries. Managerial Auditing Journal 28: 7-22. [CrossRef]

Bhatti, Maria, and Ishaq M. Bhatti. 2010. Toward understanding Islamic corporate governance issues in Islamic finance. Asian Polit. Policy 2: 25-38. [CrossRef]

Black, S. Bernard, Antonio Gledson De Carvalho, and Erica Gorga. 2010. Does one size fit all in corporate governance? Evidence from Brazil (and other BRIK Countries). In ECGI Law Working Paper No.30. Evanston: Northwestern University. 
Buchanan, G. Bonnie, Quan V. Le, and Meenakshi Rishi. 2012. Foreign direct investment and institutional quality: Some empirical evidence. International Review of Financial Analysis 21: 81-89. [CrossRef]

Buck, Trevor, and Azura Shahrim. 2005. The translation of corporate governance changes across national cultures: The case of Germany. Journal of International Business Studies 36: 42-61. [CrossRef]

Büthe, Tim, and Helen V. Milner. 2008. The politics of foreign direct investment into developing countries: Increasing FDI through international trade agreements? American Journal of Political Science 52: 741-62. [CrossRef]

Cai, Francis, and Hannah Wong. 2010. The effect of IFRS adoption on global market integration. International Business and Economics Research Journal 9: 25-34. [CrossRef]

Chen, Charles J. P., Yuan Ding, and Bin Xu. 2014. Convergence of accounting standards and foreign direct investment. The International Journal of Accounting 49: 53-86. [CrossRef]

Covrig, M. Vicentiu, Mark L. Defond, and Mingyi Hung. 2007. Home bias, foreign mutual fund holdings, and the voluntary adoption of international accounting standards. Journal of Accounting Research 45: 41-70. [CrossRef]

Daskalopoulos, Evangelos, Anastasios Evgenidis, Athanasios Tsagkanos, and Costas Siriopoulos. 2016. Assessing variations in foreign direct investments under international financial reporting standards (IFRS) adoption, macro-socioeconomic developments and credit ratings. Investment Management and Financial Innovations 13: 36-48. [CrossRef]

Dkhili, Hichem, and Lassad Ben Dhiab. 2018. The Relationship between Economic Freedom and FDI versus Economic Growth: Evidence from the GCC Countries. Journal of Risk and Financial Management 11: 81. [CrossRef]

Dunning, H. John, and Sarianna M. Lundan. 1998. The geographical sources of competitiveness of multinational enterprises: An econometric analysis. International Business Review 7: 115-33. [CrossRef]

Gani, Azmat. 2007. Governance and foreign direct investment links: Evidence from panel data estimations. Applied Economics Letters 14: 753-56. [CrossRef]

Globerman, Steven. 2017. A new era for foreign direct investment? Multinational Business Review 25: 5-10. [CrossRef]

Gopinath, Munisamy, Daniel Pick, and Utpal Vasavada. 1999. The economics of foreign direct investment and trade with an application to the US food processing industry. American Journal of Agricultural Economics 81: 442-52. [CrossRef]

Gordon, A. Lewrence, Martin P. Loeb, and Wenjie Zhu. 2012. The impact of IFRS adoption on foreign direct investment. Journal of Accounting and Public Policy 31: 374-98. [CrossRef]

Guerin, S. Selen, and Stefano Manzocchi. 2009. Political regime and FDI from advanced to emerging countries. Review of World Economics 145: 75-91. [CrossRef]

Hassan, A. Enas, Michaela Rankin, and Wei Lu. 2014. The development of accounting regulation in Iraq and the IFRS adoption decision: An institutional perspective. The International Journal of Accounting 49: 371-90. [CrossRef]

Hausman, Jerry A. 1978. Specification Tests in Econometrics. Econometrica 46: 1251-71. [CrossRef]

Hodgdon, Christopher, Rasoul H. Tondkar, David W. Harless, and Ajay Adhikari. 2008. Compliance with IFRS disclosure requirements and individual analysts' forecast errors. Journal of International Accounting, Auditing and Taxation 17: 1-13. [CrossRef]

Hussain, Mumtaz, Muhammad Farhan Bashir, and Umer Shahzad. 2021. Do foreign direct investments help to bolster economic growth? New insights from Asian and Middle East economies. World Journal of Entrepreneurship, Management and Sustainable Development 17: 62-84. [CrossRef]

IMF. 2018. Gulf Countries Council: Trade and Foreign Investors Key to Diversification and Growth in the GCC. Washington, DC: IMF, December 6.

Irvine, Helen. 2008. The global institutionalization offinancial reporting: The case of the United Arab Emirates. Accounting Forum 32: 125-42. [CrossRef]

Kainth, Akarsh, and Ranik Raaen Wahlstrøm. 2021. Do IFRS Promote Transparency? Evidence from the Bankruptcy Prediction of Privately Held Swedish and Norwegian Companies. Journal of Risk and Financial Management 14: 123. [CrossRef]

Kaufmann, Daniel, Aart Kraay, and Massimo Mastruzzi. 2009. Governance Matters VIII: Aggregate and Individual Governance Indicators 1996-2008. Washington, DC: The World Bank.

Kayalvizhi, P. N., and M. Thenmozhi. 2018. Does quality of innovation, culture and governance drive FDI:Evidence from emerging markets. Emerging Markets Review 34: 175-91. [CrossRef]

Khanna, Tarun, Joe Kogan, and Krishna Palepu. 2006. Globalization and similarities in corporate governance: A cross-country analysis. Review of Economics and Statistics 88: 69-90. [CrossRef]

Lambsdorff, Johann Graf. 2003. How corruption affects persistent capital flows. Economics of Governance 4: 229-43. [CrossRef]

Lederman, Daniel, Taye Mengistae, and Lixin Colin Xu. 2013. Microeconomic consequences and macroeconomic causes of foreign direct investment in southern African economies. Applied Economics 45: 3637-49. [CrossRef]

Li, Quan. 2009. Democracy, autocracy, and expropriation of foreign direct investment. Comparative Political Studies 42: $1098-127$.

Liu, Xiaming, Chengang Wang, and Yingqi Wei. 2001. Causal links between foreign direct investment and trade in China. China Economic Review 12: 190-202. [CrossRef]

Marchant, A. Mary, Dyana N. Cornell, and Won W. Koo. 2002. International trade and foreign direct investment: Substitutes or complements? Journal of Agricultural and Applied Economics 34: 289-302. [CrossRef]

Márquez-Ramos, Laura. 2011. European accounting harmonization: Consequences of IFRS adoption on trade in goods and foreign direct investments. Emerging Markets Finance and Trade 47: 42-57. [CrossRef] 
Meyer, Klaus E. 2001. Institutions, transaction costs, and entry mode choice in Eastern Europe. Journal of International Business Studies 32: 357-67. [CrossRef]

Neter, John, Michael Kutner, Christopher Nachtsheim, and William Wasserman. 1996. Applied Linear Statistical Models. New York City: McGraw Hill.

Nnadi, Matthias, and Teerooven Soobaroyen. 2015. International financial reporting standards and foreign direct investment: The case of Africa. Advances in Accounting 31: 228-38. [CrossRef]

Nurunnabi, Mohammad. 2018. Perceived costs and benefits of IFRS adoption in Saudi Arabia: An exploratory study. Research in Accounting Regulation 30: 166-75. [CrossRef]

Papaconstantinou, Panagiota, Athanasios G. Tsagkanos, and Costas Siriopoulos. 2013. How bureaucracy and corruption affect economic growth and convergence in the European Union: The case of Greece. Managerial Finance 39: 837-47. [CrossRef]

Ramanna, Karthik, and Ewa Sletten. 2009. Why Do Countries Adopt International Financial Reportingstandards? Available online: https:/ / papers.ssrn.com/sol3/papers.cfm?abstract_id=1460763 (accessed on 20 June 2020).

Sheather, J. Simon. 2009. Variable selection. In A Modern Approach to Regression with R. New York: Springer, pp. 227-61.

Shehata, F. Nermeen. 2015. Development of corporate governance codes in the GCC: An overview. Corporate Governance 15: 315-38. [CrossRef]

Shleifer, Andrei, and Robert W. Vishny. 1997. A survey of corporate governance. The Journal of Finance 52: 737-83. [CrossRef]

Slangen, H. L. Arjen, and Rob J. Van Tulder. 2009. Cultural distance, political risk, or governance quality? Towards a more accurate conceptualization and measurement of external uncertainty in foreign entry mode research. International Business Review 18: 276-91. [CrossRef]

Tintin, Cem. 2013. The determinants of foreign direct investment inflows in the Central and Eastern European Countries: The importance of institutions. Communist and Post-Communist Studies 46: 2. [CrossRef]

Tsagkanos, Athanasios, Costas Siriopoulos, and Konstantina Vartholomatou. 2019. FDI and Stock Market Development: Evidence from a 'new' emerging market. Journal of Economic Studies 46: 55-70. [CrossRef]

Villaverde, Jose, and Adolfo Maza. 2015. The determinants of inward foreign direct investment: Evidence from the European regions. International Business Review 24: 209-23. [CrossRef] 